\title{
Hubungan Pengetahuan dan Sikap Ibu Hamil tentang Olahraga selama Kehamilan di Desa Klinterejo
}

\author{
Anindya Hapsari' ${ }^{1}$, Hartati Eko Wardani' ${ }^{1}$, Dhian Kartikasari ${ }^{1}$ \\ ${ }^{1}$ Program Studi Kesehatan Masyarakat, Fakultas Ilmu Keolahragaan, Universitas Negeri Malang
}

Corresponding author: Anindya Hapsari (anindya.hapsari.fik@um.ac.id)

Received 16 August 2019; Accepted 19 August 2019; Published 5 September 2019

\begin{abstract}
ABSTRAK
Olahraga selama kehamilan bermanfaat untuk mengurangi resiko persalinan prematur, hipertensi dalam kehamilan, dan nyeri saat persalinan. Namun, pengetahuan mengenai manfaat olahraga selama kehamilan tidak dimiliki oleh semua ibu hamil. Oleh karena itu, dilakukan penelitian untuk mengetahui hubungan pengetahuan dan sikap ibu hamil tentang olahraga selama kehamilan. Penelitian ini dilakukan di Ds. Klinterejo Mojokerto secara potong-lintang. Populasi dan sampel adalah seluruh ibu hamil di Ds Klinterejo sebanyak 50 orang. Data penelitian akan diolah dan menggunakan Uji Spearman dengan tingkat signifikansi 0,05. Hasil analisis ditemukan sig.0.267, yang berarti tidak ada hubungan antara pengetahuan dan sikap ibu hamil tentang olahraga selama kehamilan di Ds. Klinterejo Mojokerto. Kesimpulan dari hasil penelitian adalah bahwa pengetahuan ibu hamil tidak mempengaruhi keputusannya untuk melakukan olahraga selama kehamilan.
\end{abstract}

Kata Kunci: Olahraga selama kehamilan, Pengetahuan, Sikap

Copyright @ 2019 Institut Ilmu Kesehatan STRADA Indonesia All rights reserved.

This is an open-acces article distributed under the terms of the Creative Commons Attribution-ShareAlike 4.0 International License.

\section{PENDAHULUAN}

Angka kematian ibu (AKI) dan neonatus merupakan indikator keberhasilan pelayanan kesehatan, khususnya pelayanan kebidanan dan perinatologi. Indonesia hingga saat ini masih memiliki AKI yang cukup tinggi dan tidak mencapai target Millennium Development Goals (Adisasminto, 2008). Penyebab terbanyak kematian neonatus dan ibu melahirkan di negara berkembang, termasuk Indonesia adalah partus lama. Selain itu, sebesar 29\% kematian neonatus di negara-negara berkembang diakibatkan karena persalinan prematur (Lawn et al., 2006).

Etiologi pasti dari persalinan prematur belum diketahui. Beberapa mekanisme yang diduga menyebabkan persalinan prematur adalah adanya infeksi dan peregangan uterus patologis, yang antara lain diakibatkan terlalu banyak aktivitas fisik oleh ibu hamil (Vincenzo et al., 2002). Akan tetapi, berbagai penelitian juga menunjukkan pentingnya olahraga dan atau aktivitas fisik pada ibu hamil. Penelitian oleh Weissgerber et al pada tahun 2004 menunjukkan pentingnya olahraga teratur bagi ibu hamil untuk mencegah terjadinya persalinan prematur dan hipertensi dalam kehamilan (Weissgerber et al., 2004). Penelitian oleh Juhl et al pada tahun 2007 juga menunjukkan penurunan angka persalinan prematur sebesar $40 \%$ pada ibu dengan olahraga teratur (Juhl et al., 2007). Penelitian- 
penelitian ini dilakukan secara kohort prospektif dan tidak membatasi jenis aktivitas fisik dan atau olahraga yang dilakukan oleh subjek penelitian.

Aktivitas fisik yang paling tepat dilakukan oleh ibu hamil adalah yang tidak menahan beban perut. Contohnya antara lain: renang, bersepeda, berjalan, dan senam hamil. Akan tetapi, ibu hamil tetap dianjurkan untuk meminta persetujuan dokter spesialis obstetri sebelum memulai aktivitas fisik apapun. Selain itu, berdasarkan penelitian yang diterbitkan dalam American Journal of Obstetric and Gynecolog tahun 1989, senam teratur selama masa trimester terakhir kehamilan mampu membuat ibu mengalami persalinan yang tidak terlalu terasa sakit dibandingkan dengan persalinan ibu yang tidak rutin melakukan senam selama kehamilan. Diduga ini disebabkan kegiatan senam mampu meningkatkan kadar hormon endorphine dalam tubuh, yang merupakan antinyeri alami (Hanton, 2001).

Berdasarkan uraian di atas, dapat diketahui bahwa olahraga selama kehamilan bermanfaat tidak hanya bagi ibu yang sedang mengandung, tetapi juga pada janin dalam kandungannya. Olahraga yang dilakukan ibu hamil tidak hanya terbatas pada senam hamil saja, sekalipun senam hamil adalah olahraga yang paling populer dewasa ini. Olahraga selama kehamilan mampu mengurangi resiko persalinan prematur, hipertensi dalam kehamilan, dan mengurangi nyeri saat persalinan (Weissgerber et al., 2004; Hanton, 2001).

Akan tetapi, pengetahuan tentang manfaat olahraga selama kehamilan tidak dimiliki oleh semua ibu hamil. Akibatnya, tidak semua ibu hamil berani dan berupaya melakukan olahraga selama kehamilannya. Survey pendahuluan yang telah peneliti lakukan, menemukan bahwa dari 10 orang ibu hamil di Desa Klinterejo tidak mengetahui manfaat olahraga selama kehamilan dan tidak mau melakukan olahraga karena takut terjadi persalinan prematur. Atas dasar latar belakang ini, akan dilakukan penelitian guna mengetahui ada tidaknya hubungan antara pengetahuan dan sikap ibu hamil tentang olahraga selama kehamilan di Desa Klinterejo Mojokerto.

\section{METODE}

Penelitian dengan desain penelitian cross sectional (potong-lintang) ini mengukur variabel independen dan dependen pada pada saat yang bersamaan. Populasi penelitian ini adalah seluruh ibu hamil yang bertempat tinggal di Desa Klinterejo Kecamatan Sooko Kabupaten Mojokerto pada saat penelitian dilakukan, yang berjumlah 50 orang. Sampel diambil dengan teknik purposive sampling yang menyertakan seluruh populasi subjek penelitian. Penelitian dilakukan pada bulan OktoberNovember 2018 menggunakan sumber data primer. Data primer merupakan data hasil pengisian kuesioner oleh subjek penelitian. Instrumen yang dipergunakan adalah kuesioner untuk menilai tingkat pengetahuan ibu hamil tentang olahraga selama kehamilan dan kuesioner untuk menilai sikap ibu hamil tentang olahraga selama kehamilan. Kuesioner sikap menggunakakan skala LIKERT, yaitu berupa suatu pernyataan dengan opsi jawaban berupa sikap responden terhadap pernyataan tersebut. Opsi jawaban responden adalah: tidak pernah, kadang-kadang, sering, atau selalu (Hapsari dan Isgiantoro, 2014). Kedua kuesioner diberikan kepada responden secara bersamaan untuk diisi pada saat itu juga. Data hasil kuesioner kemudian dilakukan proses: editing, coding, scoring dan tabulating dan dianalisis menggunakan uji Spearman rho dengan taraf signifikansi $(\alpha)$ sebesar 95\%.

\section{HASIL}

\section{Pengetahuan Ibu Hamil tentang Olahraga Selama Kehamilan Di Desa Klinterejo Mojokerto}

Tabel 1 Distribusi Frekuensi Pengetahuan Ibu Hamil tentang Olahraga Selama Kehamilan di Desa Klinterejo Mojokerto Tahun 2018

\begin{tabular}{clll}
\hline No & Pengetahuan Tentang Olahraga selama Kehamilan & Jumlah & Prosentase (\%) \\
\hline 1. & Kurang & 2 & 4 \\
2. & Cukup & 19 & 38 \\
3. & Baik & 29 & 58 \\
\hline & Jumlah & 50 & 100 \\
\hline
\end{tabular}


Sumber : Data Primer 2018

Hasil penelitian pengetahuan tentang olahraga selama kehamilan menunjukkan dari 50 responden sebagian besar berpengetahuan baik yaitu sebanyak 29 responden (58\%) dan sebagian kecil berpengetahuan kurang yaitu sebanyak 2 responden (4\%).

\section{Sikap Ibu Hamil tentang Olahraga Selama Kehamilan Di Desa Klinterejo Mojokerto}

Tabel 2 Distribusi Frekuensi Sikap Ibu Hamil tentang Olahraga selama Kehamilan di Desa Klinterejo Mojokerto Tahun 2018

\begin{tabular}{clll}
\hline No & Sikap Ibu Hamil tentang Olahraga selama Kehamilan & Jumlah & Prosentase $(\%)$ \\
\hline 1. & Negatif & 18 & 36 \\
2. & Positif & 32 & 64 \\
\hline & Jumlah & 50 & 100 \\
\hline
\end{tabular}

Sumber: Data Primer 2018

Hasil penelitian sikap ibu hamil tentang olahraga selama kehamilan menunjukkan dari 50 responden sebagian besar berperilaku positif yaitu sebanyak 32 responden $(64 \%)$ dan sebagian kecil berperilaku negatif yaitu sebanyak 18 responden $(36 \%)$.

\section{Hubungan Pengetahuan dan Sikap Ibu Hamil Tentang Olahraga Selama Kehamilan Di Desa Klinterejo Mojokerto}

Tabel 3 Tabulasi Silang Hubungan Pengetahuan dan Sikap Ibu Hamil tentang Olahraga selama Kehamilan di Desa Klinterejo Mojokerto Tahun 2018

\begin{tabular}{llllllll}
\hline \multirow{2}{*}{ No } & Sikap & Negatif & Positif & \multicolumn{3}{c}{ Total } \\
\cline { 2 - 8 } & Pengetahuan & F & $\%$ & F & $\%$ & f & $\%$ \\
\hline 1. & Kurang & 2 & 11,1 & 0 & 0 & 2 & 4 \\
\hline 2. & Cukup & 7 & 38,9 & 12 & 37,5 & 19 & 38 \\
\hline 3. & Baik & 9 & 50 & 20 & 62,5 & 29 & 58 \\
\hline & Jumlah & 18 & 100 & 32 & 100 & 50 & 100 \\
\hline Sig $0.267, \alpha=0.05, \mathrm{n}=50$ & & & & & &
\end{tabular}

Hasil tabulasi silang hubungan pengetahuan dan sikap ibu hamil tentang olahraga selama kehamilan di Desa Klinterejo Mojokerto menunjukkan paling banyak adalah responden yang berpengetahuan baik dan berperilaku positif. Hasil analisis uji Spearman rho ditemukan sig.0.267 $>\alpha$ (0.05). Dengan demikian H0 diterima dan H1 ditolak, yang artinya tidak ada hubungan antara pengetahuan dan sikap ibu hamil tentang olahraga selama kehamilan di Desa Klinterejo Mojokerto.

\section{PEMBAHASAN}

Hasil penelitian ini adalah sebagian besar responden berpengetahuan baik tentang olahraga selama kehamilan. Responden mampu menjawab benar sebagian besar pertanyaan kuesioner yang meliputi: definisi, manfaat, macam olahraga selama kehamilan, dan kontraindikasi olahraga selama kehamilan. Pengetahuan (knowledge) diartikan sebagai hasil dari tahu. Pengetahuan diperoleh setelah penginderaan terhadap sesuatu dilakukan oleh seseorang (Notoatmodjo, 2011). Faktor yang mempengaruhi pengetahuan, yaitu: faktor internal (pendidikan, minat, pengalaman, usia) dan eksternal (ekonomi, informasi, dan kebudayaan lingkungan) (Putri, 2017). Tingginya pengetahuan responden atau ibu hamil tentang olahraga selama kehamilan dapat dipengaruhi oleh berbagai faktor yang telah disebutkan.

Pengetahuan merupakan salah satu faktor penting untuk membentuk sikap seseorang (Notoatmodjo, 2011). Sikap atau perilaku dihasilkan sebagai reaksi atas rangsangan dari luar, antara 
lain pengetahuan (Wawan dan Dewi, 2010). Hasil penelitian menunjukkan bahwa sikap olahraga selama kehamilan sebagian besar responden adalah positif. Hal ini berarti sebagian besar ibu hamil sudah melaksanakan olahraga selama masa kehamilannya. Hasil penelitian ini mengindikasikan pengetahuan ibu hamil tidak mempengaruhi keputusannya untuk melakukan olahraga dalam kehamilan. Ibu hamil dengan pengetahuan cukup sudah melakukan olahraga selama kehamilan. Hal ini mengindikasikan ada faktor-faktor lain selain pengetahuan yang mempengaruhi keputusan ibu hamil dalam melakukan olahraga.

\section{KESIMPULAN}

Kesimpulan dari penelitian ini adalah tidak didapatkan adanya hubungan antara pengetahuan dan sikap ibu hamil tentang olahraga selama kehamilan di Desa Klinterejo Mojokerto dengan hasil uji Spearman rho sig.0.267 $>\alpha(0.05)$. Peneliti menyarankan perlunya dilakukan penelitian lanjutan untuk mengetahui faktor-faktor yang mempengaruhi ibu hamil dalam melakukan olahraga selama kehamilan.

\section{REFERENSI}

Adisasminto, \& Wiku. (2008). Analisis Politik Nasional dan Millenium Development Goals MDG. Jakarta: FKM UI.

Hapsari, A., \& Isgiantoro. (2014). Pengetahuan Konjungtivitis pada Guru Kelas dan Pemberian Pendidikan Kesehatan Mencuci Tangan pada Siswa Sekolah Dasar. KESMAS Jurnal Kesehatan Masyarakat Nasional, 8(8), 366-372.

Juhl, M., Andersen, P., G., Olsen, J., Madsen, M., Jorgensen, T., Nohr, E., A., \& Andersen, A., N. (2007). Physical Exercise during Pregnancy and The Risk of Preterm Bierth: A Study within the Danish National Birth Cohort. American Journal of Epidemiology, 167(7), 859-866.

Lawn, J., E., Wilczynska-Ketende, K., \& Cousens, S., N. (2006). Estimating the causes of 4 million neonatal deaths in the year 2000. Int J Epidemiol 2006; 35: 706-18.

Notoatmodjo, S. (2011). Pendidikan dan Perilaku Kesehatan. Jakarta: PT Rineka Cipta.

Putri, R. (2017). Hubungan antara Tingkat Pendidikan dan Tingkat Pengetahuan dengan Perilaku Hidup Sehat Kualitas Lingkungan Rumah, (Online), (http://digilib.unila.ac.id), diakses 23 Januari 2019.

Vincenzo, B., Mark, K., Cora, McP., Cristopher, C., John, C., H., \& Philip, H. (2002). Sexual Intercourse Association with Asymptomatic Bacterial Vaginosis and Trichomonas Vaginalis Treatment in Relationship to Prematur Birth. Am J Obstet Gynecol. 2002;1987:1227-82.

Wawan, A., \& Dewi, M. (2010). Teori \& Pengukuran Pengetahuan, Sikap, dan Perilaku Manusia. Yogyakarta: Nuha Medika.

Weissgerber, T., L., Wolfe, L., A., \& Davies, G., A., L. (2004). The Role of Regular Physical Activity in Preeclampsia Prevention. Medical Science Sports Exercise 2004;36 (12). 